\title{
Management in care of older persons and persons with disabilities in Sweden
}

\author{
Maria Wolmesjö E Annelie Gollungberg
}

Maria Wolmesjö, PhD is Researcher, Assistant Professor, Head of Department of Social Work/ISV, Linköping University, Sweden. Annelie Gollungberg is Director of Social Care, Municipality of Alvesta, Sweden.

\begin{abstract}
This article gives a brief description of management in the care of older persons and persons with disabilities in Sweden. The focus is on how the management profession has developed and what competence is required to reach the goal of providing good quality social care. Current practice challenges and realities indicate that one of the difficulties faced by managers is to provide older persons and persons with disabilities with the possibility of participating in a social context despite a disability or illness. Examples are given of how to secure the individual's rights on a local, regional and national level.
\end{abstract}

\section{Introduction}

Management in social work in Sweden, and more specifically in the care of older persons and persons with disabilities, is a complex field. New problems and their solutions are often related to leadership and management. The manager's role in social care is in the process of change at the present time. The position is an intermediate one in a hierarchical organisation, termed as 'the hamburger syndrome' since they are squeezed between on the one hand, politicians and higher-level management, and on the other hand, staff members and care receivers. These are different groups with differing demands on the manager. The position gives the manager an important role in the interplay between the different groups and their different domains. It has been established that the demands on managers in social care of older persons and persons with disabilities has increased in recent years (Wolmesjö, 2005) as is the case in other fields in social work and the public sector in general. The picture that appeared in Wolmesjö's study (2005) shows that these demands can be described in terms of balancing calls for effectiveness and efficiency, mostly from politicians and managers on higher levels, with those for communication from employees and clients / users. The solution is related to the development of (new) competence. The questions raised are: what type of competence is needed and which direction should be taken in terms of social care management education and by social care organisations? Is it towards effectiveness and efficiency and with the emphasis on management - strategic leadership or towards communication with the emphasis on leadership - operative leadership?

\section{Focus of the discussion}

The aim of this article is to focus on the manager in the care of older persons and persons with disabilities. The main question is how he/she works in accordance with the statutory 
rights for the different groups mentioned above in order to be able to participate in normal life in the community regardless of age, disability and/or illness. The paper contains a brief description of how the role of the manager has developed, with a focus on the qualifications needed to provide good quality social care and a focus on current practical challenges and realities.

\section{Method}

The paper focuses on recent research on leadership in transformation and on how politicians and managers view experience as well as describing management and leadership in different types of organisations within the social work field - in particular the care of older persons and persons with disabilities (Wolmesjö, 2005). The paper also includes a study of a group of managers who participated in a focus group where management and leadership in the public sector were discussed. In the group, a total of three women took part. All of them worked as managers/ directors in the care of older persons and persons with disabilities in the municipality of Alvesta in southern Sweden. The group members themselves raised the issues that were discussed and little prompting from the focus group leader was needed. Each of the three sessions were recorded and transcribed.

\section{History of social policy and reforms}

In the last 100 years, the municipal care of older persons and persons with disabilities has developed radically; from taking care of the poor in the early 20th century, through 'poor houses' and homes for older persons, to special residential solutions and home care and the possibility of receiving a high standard of social care and health care at home by the beginning of the 21st century. Major changes took place during the 1990s that have affected the organisation of care, leadership and social and health care (Blomberg, Edebalk \& Petersson, 1999; Olsson \& Ingvad, 2000). The welfare state in Sweden at the millennium was subjected to decentralisation, reorganisation and financial cutbacks (Bäckman. 2001, p. 190). The major reforms and Swedish Code of Statues relevant for this paper are: the Elderly Reform (1992), The Disability Act (1994) and the Mental Health Reform (1995).

The municipal support and service for older persons and persons with a disability are offered to a heterogeneous group of persons; for example with varying ages, gender, ethnicity, disabilities and needs. Furthermore different professions and professional cultures have to cooperate. Traditions and cultures from different eras and different educational backgrounds affect the public sector social care and the political ideology of the governing parties also varies over time. The care of older persons and persons with disabilities can thus be described as a complex organisation where different traditions meet. It is in this complex organisation of the public sector social care that managers have to lead, but even among managers there are different traditions of leadership and educational cultures.

What special knowledge and formal education do municipal managers have in general? Research about professional knowledge, competence and education in management in the social care sector is relatively rare in Sweden. It is important to understand leadership in social work since the profession itself has changed (Rank \& Hutchinson, 2000, p. 487). In the last century the most common training for directors / managers in social care in Sweden developed from a practical course of six months to a three and a half year academic degree 
course at university level, that is, a Bachelor of Science in Social Work. The assignment for the former home help manager has transformed from a focus on caring and nursing through a focus on carrying out care assessments to an administrative profession as a divisional director with responsibility for the provision of services, the budget and the employees.

\section{Trends in leadership}

Since the early 20th century, the role of leaders has changed from a patriarchal ideal where personal qualifications or characteristics were predominant, towards a more professional role. A discussion about efficiency in the public sector was inherited from the Scientific Management School, which had its roots in Taylor's conveyor belt. During the late 20th century the leaders began to receive their legitimacy through professional, formal merits. Rules and routines gained power in organisations (Matti, 2006).

The communication discourse has its background in the Human Relation School. In the 1970s the role of the manager developed towards a role where the primary focus was on impacting the employees' behaviour rather than on exerting control (Wilson, 1995, p. 33) and this soon became the predominant model in management education. Theory and exercises in group dynamics were on the agenda in leadership courses.

During the 1980s, self-managed group teams became popular in different kinds of organisations. Wilson (1995) spoke of a revolution and offered an alternative for work organisation. When the staff members themselves can be part of the organisation, develop new skills and use their competence, a change in the organisation can be generated. This change demands a new type of management and new attitudes. The new manager has to motivate, support and encourage and make it possible for staff members to 'develop'. In this period the Bachelor of Science Degree in Social Care/Social Work was introduced in Sweden. The programme was developed to educate managers at different levels in the care of older persons and of persons with disabilities.

During the 1990s the programme was further developed within the social science field with focus on the science of social work. At the millennium the focus in social work management education was on human relations and the personal development of the manager. Training in coping with conflicts and training group processes were popular issues. The focus is still on relational aspects of leadership, that is, the contact between managers and their employees and the relationships between employees.

Another important issue is an understanding of the main goals of the municipal organisation and an understanding of how globalisation processes affect the organisation. Ten years after the millennium, we now have a three-and-a-half year university degree course (210 ECTS Credits) and the basic study programme covers different aspects of social work. Students are able to select specialist courses if they want to develop specific knowledge of management. The social work programme is offered at approximately 16 universities and colleges in Sweden and attracts a large number of students every year. The municipalities also arrange a variety of in-house training for their managers in the social care field.

The conclusion from the above is that management theories help to explain either how leadership has developed or how management is best performed and what effects it has (Hagström, 1990). Focus in the research on management and leadership has moved from the 
perspective of leadership related to the qualities of the individual leader, to the perspective of leadership related to a situation, that is, how the manager reacts to different situations. It is common for contemporary management researchers (Fernler, 2003; Holmberg \& Henning, 2003; Tullberg, 2003) to explain leadership as a relationship between the leader and those who are led. Leadership is explained as a social construction, that is, it is developed in interaction between the leader and the led and is formed by the manager (the leader) together with the staff members (the led).

According to one of our respondents in the focus group interview, who has long experience as a manager in this field: '20 years ago there were a lot of things to be done, 90 percent of these were already planned tasks and the medical aspects had a big influence on my daily work.' She had daily contact with the older persons in her charge. Twenty years later her task is to work via the employees in order to attain a good quality of care for the older persons.

It is only by giving the employees a goal to focus on that I can reach my goals. How can I create these possibilities? Which resources and how much freedom to act can I have in a public sector, politically led organisation? How can I have an impact on the development through my leadership?

These questions indicate new challenges for managers to cope with.

Our respondents sometimes express difficulties in describing their management or leadership in theoretical terms as above or saying what they actually do as managers or why they have chosen or become a manager. 'You are as you are', as one of our respondents explains it. At the same time, they point out that, by taking part in different management courses they have the opportunities to get time for personal reflection. One example of knowledge gained in these courses is the importance of thinking as a leader 'you have to be able to lead yourself' (time management).

\section{Population served}

Approximately 1.5 million Swedes are 65 -years old or older (17\% of the population). Some 482,000 of these are 80 -years old or more ( $5 \%$ of the population), which means that Sweden has the oldest population of all countries in the world in terms of the proportion of people over 80 (National Board of Health and Welfare, 2009). The number of older persons, 80 years plus, has increased by 17 percent between 1990 and 1998 (Szebehely, 2000). The average life expectancy is 78 years for men and 82 years for women (Sweden.se, 2006). According to this, life expectancy has increased by 25 years in Sweden since the beginning of the 19th century (Statistiska centralbyran, 2009 (SCB.se)).

Since 1980 the financial situation of the population has changed in Sweden, and today only the neediest, receive municipal social care. Those with need of daily personal assistance are prioritised. Twenty-five years ago $62 \%$ of the population over 80 years of age received municipal home help or had a place in housing for older persons. By 2000 this figure had been reduced to $44 \%$. An explanation is that services are offered from private caregivers or relatives and older people wait longer to move to special housing than they did previously. There are a larger number of older women than men in home care since women live longer, they more often live alone and have more medical problems than men. However it has been found that men receive more home help care and services and have been assigned a place in 
housing for older persons in a shorter period of time than women with similar needs (Prop. 2005/2006:115 [National Development Plan for the Elderly]).

In 2003 there were 235,400 persons working in the local authority care of the older persons and persons with disabilities in Sweden. Ninety percent of these staff members were women and 9,111 worked in managerial positions (Sv. Kommunförbundet, 2004; SCB, 2005). The municipalities are one of Sweden's largest labour markets and even more people come into contact with this organisation as users or relatives. Recently the number of private caregivers has increased, and the number of managers/directors and nursing assistants at different levels working in public health or social care has been reduced (SCB, 2009).

\section{Government agencies responsible for policies and practices}

In Sweden most of the welfare services are provided by the public sector - state and local authorities; the municipalities and county councils (The National Board of Health and Welfare, 2009). The framework for the activities of these actors at the local level is laid down by Parliament through legislation and decisions regarding local government financing (Government Office in Sweden, 2009). The largest sector within the municipalities' financial responsibilities is social care and health care. The expenditure is mainly funded through taxes, social insurance contributions and patient fees for services and health care.

The government's aim for welfare policy is based on democracy and the objective of the policy is to reduce the discrepancies between different groups. The aim is to provide security in all phases of life and the opportunity to develop an acceptable economic standard (The National Board of Health and Welfare, 2009). Everyone shall have equal opportunities, rights and obligations to take part in society, working life and to make use of their resources, irrespective of economic or social background (Government Office of Sweden, 2009).

In 2005 the government presented a National Development Plan for the Health and Social Care of older persons for the next 10-year period (Prop. 2005/2006:115). The purpose of the plan was to unite the authorities at municipal, regional and government levels around a common perspective on the needs for development. The fields that are to receive priority are: health and social care of those with serious illnesses, security in housing, the social care, national common guidelines and local development, prevention and the employees. A focus on a user perspective will be emphasised in all the aforementioned prioritised fields.

At the municipal level each local authority has the responsibility to provide social care and service to all their inhabitants. The local political aims can vary between different municipalities. High-level administrative staff and managers in social care at different levels have the responsibility for running their organisations in accordance with the stated aims and for providing good care and service for older persons and persons with disabilities. At lower levels in the organisation employees will be given greater responsibility in decision-making. Greater levels of user influence and user participation will be attained by user representation in these groups.

\section{Working in a political organisation}

The municipal care of older persons and persons with disabilities is part of the public sector and is a politically controlled and managed organisation, that is, democratically elected 
politicians have the ultimate responsibility for formulating goals and overall policy decisions. The politicians are chosen for a period of four years and thus, goals and overall decisions can be subject to change rather often at local level, reflecting changes in political majorities. An important task for managers is to negotiate between different organisational levels and discourses in terms of their intermediate position. In reality, the management is often involved in the (political) organisational planning. This situation (the politically controlled management), is described as one of the facts that impacts the leadership of managers in social care. An important difference between working in the public and the private sectors is the demands on openness for insight from the media and the general public in the public sector (Wolmesjö, 2005).

As a manager one is responsible for providing quality care for elderly persons in accordance with Swedish legislation. The major purpose and overall goals for the care of older persons and persons with disabilities are stipulated in the Social Services Act 2001 (Swedish Code of Statues, 2001:453). Care provision is to be based on respect for the individual's independence and integrity (Swedish Code of Statues, 2001:453 1 chap 1). The services for older persons and persons with disabilities are to be decided upon and provided in consultation and cooperation with him or her and if necessary together with other organisations (Swedish Code of Statues, 2001:453 3 chap 5). Furthermore the social services are to facilitate older persons living independently under secure circumstances and having an active and meaningful life together with others (Swedish Code of Statues, 2001:453 5 chap 4). Support at home and other services are to be provided for older persons (Swedish Code of Statues, 2001:453 5 chap 5). Persons with disabilities are to have the possibility to take part in society and live as others (Swedish Code of Statues, 2001:453 5 chap 7). With the introduction of the Disability Act 1993, in 1994 the rights of the individual were strengthened (Swedish Code of Statues, 1993:387). User influences, participation and legal rights were described as new goals in the public sector. A common dilemma for managers to cope with is when the legislation of individual rights, as described above, interferes and comes into conflict with legislation about the rights of employees.

\section{Organisational trends and their effect on management in social care}

In the early 21st century the major trend affecting the municipal social care is described as 'New Public Management', an influence from the private sector (Agevall, 2005; Wolmesjö, 2005). The market-orientation resulted in a focus upon effectiveness, consumers etc, and 'the needs assessment model' was implemented in almost $80 \%$ of the municipalities in Sweden. An effect of the implementation of this model was that the former profession of a home help administrator was divided into two new distinguishable professions: the first concerned needs assessment and decisions on the level of social care, support and service to be provided to meet those needs and the second concerned the management of service provision. The politicians maintained that the basic purpose was to ensure conformity in decisions on service provision. This model can mainly be attributed to the economic situation in Sweden at present.

Another trend that has emerged in social care has been that of Self-Managed Work Teams. This trend has also been inspired by innovations in the private sector and the Volvo Car Corporation has had an important role of introducing this model to Sweden. This trend can be related to a desire by politicians to improve the work situation and lower the level 
of work dissatisfaction among employees. An effect of this trend was that the number of managers was reduced and those remaining in the organisation were given responsibility for a larger number of employees.

A further trend, which has been common in the early 21st century, has been the decentralisation of political decisions from a national level to a regional level and from the regional down to the local level. User influence and user participation were stated as the motive for this development. Decision-making and the service that was offered was to be moved closer to those affected by the decisions. One of the respondents in the focus group interview stated that, as a consequence, new demands for a more communicative management were raised. As these varying trends appeared almost simultaneously in the organisation several managers have experienced difficulties in their leadership of larger groups of employees (Wolmesjö, 2005).

\section{Case study - municipality of Alvesta}

In our case study, the municipality of Alvesta, the aforementioned trends have affected management. The organisation has developed from being 'needs oriented' to 'goal oriented'. The greatest change is associated with the new Social Services Act 2001 (Swedish Code of Statutes 2001:453), which was introduced in its first version 1982 and further developed in 2001. The immediate effect then was a change in focus from a medical perspective to a social perspective in caregiving. The process has developed over a long period of time and staff members have gained greater responsibilities and increased their knowledge. One of our respondents explained that in the last 20 years her profession as manager in care of older persons and of persons with disabilities has changed rapidly. She started as a superintendent for an old people's home where most of her days were filled with practical social work, taking care of older persons and persons with disabilities based on a medical or individual model.

The professional title for managers in social care has also developed over the years, including home-help service manager, care assessment officer (with responsibility for decision making and providing the home help services) and a common title now is Director of services for older persons and / or persons with disability. The Director has the responsibility of municipal home services or a specific residence in one part of Alvesta. The medical responsibility is now taken care of by a registered nurse and the manager's task is to be in charge of the social care and create a balance between medical and social aspects. One of the respondents from the focus group interviews gave the following example on the responsibility and the importance of being up to date with new knowledge and being aware of what is going on around your organisation:

Living in a knowledge-based society, where new knowledge leads to a greater emphasis on providing older persons with a good quality of life and meaning in their daily lives, affects my leadership. My organisation will be checked by a specific Ombudsman for older persons at the county administration board and The National Board of Health and Welfare. Their responsibility is to ensure that services and care are provided in a correct way.

\section{Current challenges}

How have the different reforms presented above impacted on the leadership? One of the main effects of the Elderly Reform (1992) was that the responsibility for the county council 
nursing homes was transferred to the municipalities. Managers in the care of older persons and of persons with disabilities became responsible for a new group of employees (nurses, nursing assistants). Different professions and different organisational cultures had to work together: one with a 'medical' tradition and one with a 'social' tradition. At the same time there were financial constraints and the need for cost-cutting, leading to fewer hours of care, fewer apartments in residential homes. In order to ensure that the users received the necessary medical care, each municipality was obliged to employ a nurse with responsibility for local authority medical care. Ten years later the following question has been asked: who looks out for and who takes responsibility for the provision of social care?

In the municipality of Alvesta, a post as 'coordinator responsible for quality in social care' has been established. The main purpose of this post, which is one of the first of its kind in Sweden, is to be responsible for the quality of the social care provided in accordance with current legalisation and local policies. The coordinator has a supportive function in the municipal organisation with the task of ensuring the legal rights of citizens in his / her social context and monitoring experiences of daily life. The coordinator's main focus is to monitor social issues and participation for the older person and/or person with a disability. A further task for the coordinator is to have overall responsibility for the development of plans for in-house training focusing on how to develop social care of older persons and persons with disabilities. The work is carried out in close cooperation with the care managers and is described by respondents in the interviews as an important support for their management function. A concrete example of this, given in the interviews, was the training provided to increase the care assistants' knowledge of how to interact with the older person or a person with disabilities. The coordinator works with planning of courses and in-house training to develop staff members' competence in different areas.

Another task of the coordinator, who is responsible for quality assurance, is to be the link between theoretical knowledge and practical knowledge, that is, formal education and evidence-based knowledge developed in the organisation. In reality, in the beginning this was arranged by a coordinator working part-time (financed by the municipal social care organisation) at the School of Social Work, Växjö University (now Linnaeus University).

A third major task for the coordinator is to be responsible for investigations and assessments into reports of bad conditions / inconveniences. The quality assurance work in social care is documented and evaluated annually and is based on the standards of working procedures according to Investors in People, IIP (Coulshed \& Mullender, 2006). IIP is an internationally acknowledged quality scheme where the aim is to develop the employee's involvement in their work and their understanding of their role in it (Investors in People, 2006; Coulshed \& Mullender, 2006). Organisations that attain the goals in three (or four) principles; (commitment), planning, action and evaluation receive an award and a public certification.

New challenges for social care managers include an increased responsibility for the budget, new demands on responsibility for human resources/employees and new administrative routines such as new computer programs, statistics etc. These new demands have surprisingly not yet been in evidence in job advertisements, which more commonly focused on personal abilities and qualities. This was also expressed by the politicians interviewed in Wolmesjö's study (2005), where the latter stated that a manager should have the ability 
to create a positive work atmosphere promoting cooperation and development, to act as intermediary for the attainment of political goals and guidelines, and to be able to express him/ herself clearly both orally and in writing. Furthermore he/ she should have the ability to get resources and be supportive to employees.

The managers themselves (both in Wolmesjö's study, 2005 and in the focus group) state that the prevalent norms and values in the organisation are influential in terms of the way people act within the organisation. Leadership and management are described as having the ability to 'change the thinking'. When they describe what is needed in order to cope with work as a manager in care of older persons and people with disabilities they talk about strength, clarity, loyalty, pushing forward, not to be frightened - daring to go against the mainstream. It is important that they, unlike the politicians, think it is essential to have a qualification in social work in order to manage the job. A common feature in the interviews was that, regardless of organisational form, both politicians and managers thought that the managers had an important role as the bearer of values and visions. The competence that can be expected of a manager in the changing, progressing and developing organisation of municipal social care of older persons and persons with disabilities is summarised below:

1. Knowledge of political goals and guidelines and the ability to interweave these into the organisation

2. Knowledge about society, its development and how it affects the organisation. Global analysis

3. Knowledge about delegation, the ability to delegate and to balance freedom and responsibility

4. Knowledge of communication processes, to be able to deal with conflicts, to be clear in dialogue with politicians, employees, users / clients / consumers

5. Knowledge of the everyday life of persons in socially marginalised situations (older persons, persons with disabilities, drug abusers etc) and knowledge of their own organisation and its responsibilities

6. Knowledge of supervision and the ability to supervise and support employees in different situations (Wolmesjö, 2005).

The demands for such a variety of skills and knowledge from the same person might make the profession of manager in social work/social care appear to be 'a mission impossible'.

\section{Client issues}

The situation for persons with disabilities has changed rapidly since the introduction of the Disability Act in 1994 (Swedish Code of Statues, 1993:387). The law provides, among others, the right to have a personal assistant, resulting in the creation of a new profession. A further provision in the law is the right for the disabled person to have a greater say in the decision-making process concerning the organisation of the individual home help care, for example, who should assist you, how often this person/s should come and what this person/s should assist with. This service can be provided by the municipal care authority as well as private companies or user cooperatives, such as Independent Living. Persons with disabilities can also choose to be their own managers and organise their support to suit their own needs. 


\section{A case example}

One of our interviewed managers provided the following examples of current practice challenges that managers in the social care of older persons and persons with disabilities have to deal with in their daily work situation: The biggest challenge as a manager is based on:

... respect, safety, accessibility, responsibility and care of others and a common vision that we will be among the best of caregiving organisations... I would like our organisation to develop towards a more innovative one where tasks are adapted to needs, where communication can be both vertical and horizontal, where there is flexibility and where we take care of the employee's competence.

By focusing on developing the employees' competence and skills and on a dialogue about 'why am I here, for whom do I do this and how', the managers hope to ensure that older persons and persons with disabilities have individual rights and the possibilities to participate in a social context. A dilemma for the managers is that they often have to work through someone else to reach their goals and have to rely on their employees doing what is expected of them. Issues concerning quality in care are discussed and the managers are dealing with different methods to ensure that the clients actually receive the support and care that the assessment officer has deemed necessary. Our respondents stated that their most important tool as a manager was the dialogue with the staff combined with listening and thus with the help of the dialogues the processes can be started, which can further the development of the organisation.

\section{Analysis and discussion}

How is it thus possible to plan for quality in leadership in future social care? In order to know this, we need to discuss what types of social problems will be evident in the future, for example, in the next generation, around the year 2035. Which types of social problems will remain? Which will have disappeared? Which type of new problem will we have to deal with? Will we need managers in social care at all, if so, which type?

The vision of the disability policies is that the goals of full participation and accessibility for all should be reached by 2010. In the suggestions in the National Development Plan of Health and Social Care for the Elderly (Prop 2005/06:115) priority has been given for raising the quality of care for persons with dementia and the main responsibility for municipal health care has been coordinated into one organisation. Technical aids and support will have developed and hopefully the quality of life in care of older persons will have increased. There will hopefully be no longer any problem with unemployment due to the expected increased rate of older persons leaving the labour market. A risk analysis of challenges for future generations of children and young people will hopefully bring about early interventions so that they may feel mentally better than many children and young people do today. Will we have been successful in eliminating the classical social problems such as poverty, the social care of children, young people, older persons and persons with disabilities on national and an international level?

Reflections such as the above show how difficult it can be when making predictions about the future. The following factors can be significant for the development of management in social care: 
1. General social problems will remain

2. The number of older persons will increase

3. The move for a change of generations will have started

4. Large groups of employees in the social sector are nearing retirement age, even those in managerial positions.

Younger employees have to develop management skills. There is already a need of new managers in social work but there is a paradox emerging. The new MTV-generation, born in the 1970s, is sceptical about the lifestyle of their parents, born in the 1940s. They do not look for long working days, stress and staff problems according to a study by Eldestrand (2007). Instead they want a balance in life and wish to be able to combine family life with leadership responsibilities. A trend that has been noticeable is that of co-management - sharing the whole responsibility or shared management - where two persons have divided different tasks between them.

Another issue is the expectation for managers to have previous experience of work in a politically run local authority organisation. A study by the National Board of Health and Welfare (2006) about how to find and employ future managers, showed that eight out of 10 managers are being headhunted from inside local authority organisations, $43 \%$ from their own administration and 37\% from other municipalities or county councils. Only $13 \%$ have come from the private sector. A question of whether it is important to have previous knowledge of a politically run organisation as a manager in public social care can be raised. Furthermore the importance of managers having awareness of gender and multicultural aspects has been highlighted. Both men and women and persons with different ethnic backgrounds receive and work in the municipal social home help services; this brings new challenges to the organisation, challenges that have to be met by managers in social care.

\section{Following trends and foreseeing the future}

It seems surprising that the municipalities rather unreflectively and uncritically appear to adopt new organisational trends, often inspired by the private sector. The examples of new ways of managing the public sector mentioned above are New Public Management (NPM), self-managed work teams and decentralisation. All of these organisational changes displayed effects that were not expected. Focus in the organisational changes was, at the outset, put on administrators, employees or users and the effect was that a distinct leadership style was in demand and management became even more important than before. This was surprising for the municipalities and it may be hard to comprehend as earlier studies (Tullberg, 2003) had shown that managers in municipal organisations are well qualified in social sciences, that is,. considerably more than managers in other fields. It has been shown that not only social policy reforms impact on leadership, organisational reforms and personnel reforms etc, but these also change the conditions for managers in social care (Wolmesjö, 2005).

\section{Interaction between managers, employees and politicians}

It has been seen that front line local authority managers find themselves in a difficult position, squeezed between the top and bottom levels in the organisation (Rickard, 1997). They are pressurised between groups and have to be able to negotiate between different domains and discourses at political, organisational and user/ client levels. An important task for manag- 
ers is to negotiate between these different organisational levels and discourses. In order to be successful in attaining the organisation's goals, positive interaction between managers, employers and politicians is needed. The question can be asked: who are you, as a manager, supposed to show your loyalty to?

Another issue for the manager to cope with is that these professions or different groups are at different educational levels. The most difficult decisions often have to be taken by those who work at the far end of the care chain, that is, nursing or care assistants who work close to the user/client. These categories of staff are often those with the lowest formal education. An important task for managers is therefore to provide support for, prepare and make it possible for nursing or care assistants to make these decisions. In order to develop the general level of qualifications for employees in the care of older persons and persons with disabilities, the Swedish government granted SEK 450 million in 2005 and SEK 300 million in 2006 and 2007. These funds, termed 'The Qualification Ladder', have been used to improve the levels of competence for these staff in a number of different ways.

An effect of organisational changes is, as described above, that they impact on the management and how one should be as a leader, despite the focus being aimed at another group or profession. In Wolmesjö's study (2005) three different types of manager's roles were found: 'the Ballerina, the Juggler and the Acrobat'. The circus metaphor has been used since organisations with a high rate of specialisation and independently working employees can be described as a circus (Söderström, 2003) and the management as 'prima donna management' (Haikola, 2000; Ehn, 2001). The Ballerina manager has a large number of employees (150 persons) and the leadership style is associated with a high-level balancing act between different domains. The Juggler is responsible for several groups of employees. The leadership is carried out at a distance and through the delegation of specific tasks, while the responsibility remains with the manager. $\mathrm{He} /$ she has to be able to cope with juggling many different things at once. If he/she allows one group a little freedom they can become too independent and perhaps change direction, which can lead to the common goals not being attained. The Acrobat is symbolised by the most traditional management style similar to that of earlier management styles in the care of older persons and persons with disabilities. The manager often works physically close to his/her employees. The manager is always on hand to answer questions, which can be both good and bad. This leadership style was described by one informant in Wolmesjö's study as 'If I am not here, the whole organisation will collapse' (2005, p.214).

\section{Conclusions}

The role as manager in the care of older persons and persons with disabilities has changed from focusing on caregiving to care management and from operative leadership to more strategic leadership. It can also be said that the organisational form impacts on management in different ways and demands different types of leadership. This entails that different types of qualifications are needed. However, despite the organisational form of management the biggest challenge is to provide a good quality of social care for older persons and persons with disabilities. Finally management in future social care is expected to be:

Transformative - working with the transformation and development of employees (at individual and organisational level), 'transformer agents' 
Reflective - 'In order to be able to lead someone else you have to be able to lead yourself' Educational - taking responsibility for raising the levels of competence among the employees, being part of ongoing research and developing knowledge

Creative - 'Think new, think different!'

(Wolmesjö, 2006)

We have made the point that leadership is a creative process that is carried out in relation to other people. Management, in other words, demands creativity in every activity one does as a manager. Wolmesjö (2005) has, in her study of managers in the care of older persons and persons with disabilities found that the demands on managers in public sector social work are increasing. One of these demands expressed by the managers themselves was related to new assignments that demanded an intimate knowledge of public sector social work. An example of this need for social work knowledge was given by the managers when describing their responsibility for social documentation and the need to motivate, educate and supervise their employees in this process. The need for a social work perspective has been expressed by the respondents in this field study.

\section{Author's contact details}

Maria Wolmesjö, Department of Social Work/ISV, Linköping University, SE 60174 Linköping, Sweden. E-mail: maria.wolmesjo@liu.se

\section{References}

Agevall, L. (2005). Välfärdens organisering och demokratin - en analys av New Public Management. Växjö University Press.

Bäckman, O. (2001). Med välfärdsstaten som arbetsgivare - arbetsmiljön och dess konsekvenser inom välfärdstjänsteområdet på 1990-talet. I M. Szebehely (red). Välfärdstjänster i omvandling. Kommittén Välfärdsboksslut. SOU 2001:52 Stockholm: Fritzes.

Blomberg, S., Edebalk, P.-G. \& Petersson, J. (1999). Äldreomsorg utan service-en framgångsrik strategi? Meddelanden från Socialhögskolan. 1999:1 Lund: Socialhögskolan, Lunds universitet.

Coulshed, V. \& Mullender, A. (2006). Management in social work. Basingstoke: Palgrave Macmillan.

Ehn, B. (2001). Universitetet som arbetsplats. Reflektioner kring ledarskap och kollegial professionalism. Lund: Studentlitteratur.

Eldestrand, A. (2007). Framtidens framgångsrika ledare. Chefer och organisationer som lyckas. In: Kairo's Future Nyhetsbrev Watching Nr 6, 2007.

Fernler, K. (2003). Offentligt ledarskap och kunskapens osäkerhet. I I. Holmberg \& R. Henning (red) (2003). Offentligt ledarskap. Om förändring, förnyelse och nya ledarideal. Lund: Studentlitteratur.

Government Office of Sweden. (2009). Retrieved from www.riksdagen.se 2009-11-12.

Hagström, B. (1990). Chef i offentlig förvaltning. Forskning kring offentligt ledarskap. Lund: Studentlitteratur.

Haikola, L. (2000). Att dirigera solister: om ledning och ledarskap vid Lunds universitet. Lund: Utvärderingsenheten. Univ.

Holmberg, I. \& Henning, R. (red) (2003). Offentligt ledarskap. Om förändring, förnyelse och nya ledarideal. Lund: Studentlitteratur.

Investors in People Scheme. (2006). Retrieved from http:/ / www.investorsinpeople.co.uk/pages/Home.aspx, accessed 21.03.11.

Matti, T. (2006). Professionella patriarker: svenska storföretagsledares ideal, praktik och professionaliseringsprocess 1910-1945. Uppsala: Acta Universitatis Upsaliensis, Universtitetsbiblioteket. Diss. Stockholm: Elander, Gotab.

National Board of Health and Welfare/Socialstyrelsen. (2006). Nationell utvecklingsplan för vård och omsorg om äldre. Prop. 2005/ 06:115. Retrieved from www.socialstyrelsen.se 2006-06-20.

National Board of Health and Welfare/Socialstyrelsen. (2009). www.socialstyrelsen.se 2009-11-12.

Olsson, E., \& Ingvad, B. (2000). Köp, sälj och platta till! Organisations-förändringar, arbetsmiljö och omsorgskvalitet $i$ hemtjänsten under 1990-talet. Meddelanden från Socialhögskolan 2000:7. Lund: Univ. Socialhögskolan.

Prop. 2005/2006:115. Socialdepartementet (2006-03-16). National utvecklingsplan för vård och omsorg om alder. 2005/2006, 115.

Rank, M. G., \& Hutchison, W. S. (2000). An analysis of leadership within the social work profession. Journal of Social Work Education, 36(3), 487-502. 
Rickard, E. (1997). I första linjen: arbetsledares mellanställning, kluvenhet och handlingsstrategier i tre organisationer. Diss. Sociologiska institutionen. Univ. Lund.

Statistiska centralbyrån. http:/ / www.scb.se.

SCB. (2005). Kommunfolkmängd efter kön och ålder 1 November 2004.

SCB. (2009). Yrken i riket eller uppdelat på kommun, Statistiska centralbyrån. Retrieved from http: / / www.scb.se 200911-16.

Söderström, M. (1990). Det svårfångade kompetensbegreppet. Pedagogisk forskning i Uppsala 94. Uppsala universitet. Svenska Kommunförbundet. (2004). Kommunal Personal 2003. Personal-statistiken 40 år. Stockholm: Svenska Kommunförbundet, utredningssektionen.

Sweden.se. (2006). http: / / www.sweden.se.

Swedish Code of Statutes, 1993:387. The Law of Support and Service/Lag om stöd och service till vissa funktionshindrade. Retrieved from http:/ / www.rixlex.riksdagen.se.

Swedish Code of Statues, 2001:453. The Social Service Act/Socialtjänstlag. Retrieved from http:/ / www.rixlex.riksdagen.se.

Szebehely, M. (2000). Äldreomsorg i förändring - knappare resurser och nya organisationsformer. I M. Szebehely (red). (2000). Välfärd, vård och omsorg: Antologi från Kommittén Välfärdsbokslut, SOU 2000:38 Stockholm Fritzes.

Pedagogiska institutionen.

Tullberg, M. (2003). Tyvärr, så är det ju ofta fel personer som blir chefer här... In I. Holmberg \& R. Henning. (red). (2003). Offentligt ledarskap. Om förändring, förnyelse och nya ledarideal. Lund: Studentlitteratur.

Wilson, G. K. (1995) Självstyrande team: den flexibla vägen till goda prestationer. Göteborg: ISL FörlagAB. Institutet för säljträning och ledarutveckling. English title: Self Managed Teamworking.

Wolmesjö, M. (2005). Ledningsfunktion i omvandling. Om förändringar av yrkesrollen för första linjens chefer inom den kommunala äldre- och handikappomsorgen. Lund: Socialhögskolan, Lunds universitet. Doctoral Dissertation in Social Work.

Wolmesjö, M. (2006). Ledarskap i framtidens socialtjänst. Paper presented at conference, Stockholm, June 2006. 